\title{
Self-consciousness and the book for students
}

Students' books have at least one thing in common with fairy stories: they are written for the use of one section of the population by another. The authors of students' books are people who teach students and who pretend, sometimes accurately, to know what students need to know. Patronizing though this convention may seem, it appears to have survived even the fierce confrontation between students and teachers of the 1960s. The groups of students with ambitions then to help shape the university curriculum, often by the addition of "socially relevant" studies, seemed implicitly to accept that even though what to teach might be up for grabs, how to teach was for teachers to decide. Teachers have been more than willing to follow this prescription. In this convention, the contributors to the symposium of reviews of students' books which follows are teachers not students.

But does not this practice include a dangerous risk of circularity? If teachers write students' books, review them in journals such as Nature and also recommend them to their students, is there not a possibility that teachers' preconceptions of what students need will be self-justifying prophecies? At the level of the secondary school, there is ample evidence that this danger is not fanciful. Until the early 1960s, in Europe and North America, most science courses were marked by an almost ostentatious neglect of modern (or postwar) science. Now, some crusty teachers (mostly outside schools) argue, the pendulum has swung too far in the opposite direction. Students at schools learn about the relevance of DNA to human genetics before they know the first thing about the hydrogen bonds that hold these molecules together. Both the old and the new conventions about the content of science courses are indeed determined by teachers, acting as often as members of examination boards or members of curriculum study groups as in the classroom. Fortunately, the dangers are less serious at the level of the university.

The most obvious safeguard is the incoherence of the market in which the would-be authors of students' books must make their way. At some point in a teaching career, the impulse to see a successful course between hard covers, and launched on a wider world than that of the teacher's own university, seems to take hold. Publishers are willing accomplices, in normal times eager to make sure that their own portfolio of standard course books is comprehensive enough for them to offer almost everything to almost anybody (and also to keep their sales forces productively employed). Given only a modicum of independent judgement by teachers who are not themselves the authors of books, there is every reason to hope that the most intellectually successful course books will be those that sell most widely. Even when it seems that the simple influence of the market may be distorted by extraneous considerations - a textbook by a well-known author or from a distinguished institution - there is no serious reason to fear that students' teachers fail to recommend books honestly.

But is it proper that the important task of educating students should be determined in such a haphazard way? Might it not be better that university students, like those in schools, should be provided with books and other teaching materials that are the product of a self-conscious examination of students' needs. In short, should universities borrow from the schools and embark on deliberate curriculum development? In the past decade and more, this challenge has been cheerfully accepted in several places and in many fields of study. Groups of university teachers have spent their weekends hammering out a logical structure for some course of instruction, have gone back to their classrooms to try out the ideas on their students and have in the end subscribed their names to the title pages of one or more books. The result is not always the unsatisfactory compromise that might be expected. Especially when the objective is to devise a teaching course that crosses established disciplinary lines, the product of these endeavours may be stimulating and valuable. If, for example, the objective is to give the teaching of a subject a greater sense of history (a crying need in most fields, especially in mathematics), most practising subject teachers will acknowledge that they could profitably make use of help from others. To the extent that course-books are increasingly the product of several people who work together as a teaching team, some of the more obvious objectives of curriculum development are already assured. Yet formal curriculum development has inevitably hung fire outside the schools. Why should this be?

Some parts of the explanation are self-evident. Good teachers are rightly as suspicious of the all-embracing course-book as their better students are resentful of the intellectual straitjacket it represents. One essential part of a university education is to learn, mostly by hard experience, how to gather different nuggets of understanding from various sources, many of them books. The course-book is thus potentially an enemy of learning, a crutch and not a challenge. Second, those who teach in universities quite properly hold that it is their duty to teach their subjects in distinctive ways. It would be a great misfortune if this principle were eroded, for teaching is at its best a creative process.

These are sufficient reasons why a certain degree of anarchy in the production of students' books is to be welcomed. Another is that many books, originally devised as books for students, have become important components of the scientific literature. Feynman's three-volume Lectures in Physics has been for the past twenty years as much a challenge to his peers as to the undergraduates at the California Institute of Technology to whom the lectures were first delivered. In the same field but in a very different style, Max Born's Atomic Physics remains a classic of succinctness and a good read, even though the subject has been transformed in the past half century. R. H. Fowler's Statistical Mechanics, an enthralling graduate textbook, illustrates a different point; when amended to take more explicit account of the relationship between statistical mechanics and thermodynamics (as Statistical Thermodynamics, by Fowler and E. A. Guggenheim), the result was awkward and too didactic. Plainly, self-consciousness can be dangerous.

Self-consciousness is nevertheless not entirely to be outlawed. Indeed, there are many points in the undergraduate curriculum at which there is an urgent need of it. Why is it, for example, that chemists and physicists are still taught thermodynamics as if they were being taught quite different things? Why is the physics of engineering so different from physics as taught in physics departments? Why is the common ground between undergraduate organic chemistry and biochemistry so hard to find? Why are there nearly as many different kinds of "mathematics" as there are universities at which mathematics is taught? Why, throughout the undergraduate teaching of science, do teachers embark apparently independently on the design of experiments and projects, unable to profit from what has been done elsewhere? The dangers of self-consciousness notwithstanding, is it not time that university teachers wrestled more diligently with these problems? 